\title{
Influence of Phosphorous and Foliar Nitrogen on the Growth, Quality and Yield of Kasuri Methi (Trigonella corniculata L.)
}

Abhinav Kumar Yadav, S.P. Singh, D.K. Yadav,

Govind Kumar Yadav, Kuldeep Singh, Mahendra Yadav

10.18805/LR-4712

\begin{abstract}
Background: Nitrogen and phosphorus are amongst fundamental macronutrients, which are crucial for the growth and development of plant. Soils of dry land of central Rajasthan are deficit in nitrogen and phosphorus content which leads to lower productivity of kasuri methi. Therefore, adequate supply of nitrogen (foliar spray) and phosphorus could enhance productivity of kasuri methi.

Methods: The experiment consisted of sixteen treatment combinations including four levels of phosphorus (control, 20, 40 and $60 \mathrm{~kg} / \mathrm{ha}$ ) and four levels of foliar application of nitrogen (control, 1.0, 1.5 and 2.0\%). They were under taken in FRBD with three replications. Result: Growth parameters and yield of fresh and dried leaves of the crop increased almost linearly with increasing levels of phosphorus and foliar application of nitrogen. The result indicated that application of phosphorus $60 \mathrm{~kg} / \mathrm{ha}$ and foliar nitrogen @ $2.0 \%$ to the kasuri methi crop significantly increased the plant height $(\mathrm{cm})$ and leaf area per plant $\left(\mathrm{cm}^{2}\right)$ at each harvest, number of nodules per plant (58.17 and 53.33, respectively) and chlorophyll content $(2.32$ and $2.39 \mathrm{mg} / 100 \mathrm{~g}$, respectively), fresh leaves yield (139.1 and 141.66 $\mathrm{q} / \mathrm{ha}$, respectively), dry leaves yield (20.01 and $22.38 \mathrm{q} / \mathrm{ha}$, respectively), protein content in leaves (5.28 and $5.75 \%$, respectively) and ascorbic acid in leaves (218.15 and $222.42 \mathrm{mg} / 100 \mathrm{~g}$, respectively).
\end{abstract}

Key words: Foliar nitrogen, Kasuri methi, Legume, Nodules, Phosphorus.

\section{INTRODUCTION}

Fenugreek is an important rabi season crop in India. There are two economically important species of the genus Trigonella viz., Trigonella foenum-graecum (common methi) and Trigonella corniculata L. (Kasuri methi). Kasuri methi is also called as "Champa methi" and "Marwari methi". It is mainly grown as leafy vegetable and for seeds in the plains of North India. Kasuri methi (Trigonella corniculata L.) is a slow growing plant that remains in a rosette condition during vegetative growth. It bears bright orange-yellow flowers, which are borne on long stalks. Pods are 2-3 cm long, sickle shaped and seeds are smaller and scented. Kasuri methi is suitable for 5-8 leaf cuttings. Its seeds mature in 150-160 days after sowing. Its fresh leaves and pods are fried and consumed as vegetable.

Fenugreek occupied prime place amongst the seed spices grown in Northern India particularly in Rajasthan. Out of the total 63 spices grown in India, 20 are classified as seed spices with $36 \%$ share in area and $17 \%$ share in production of total spices (Anwer et al. 2011). The crop is cultivated in the country over an area of 149.0 thousand Ha, producing 202.0 thousand tonnes with 1.4 ton/ha productivity (Anonymous, 2017). It is grown on an extensive scale in Rajasthan, Madhya Pradesh, Gujarat, Uttar Pradesh, Maharashtra and Punjab. In Rajasthan, fenugreek is largely cultivated in Jaipur, Nagore, Sikar, Bharatpur, Bikaner, Sriganganagar, Jodhpur, Jalore, Kota, Udaipur and Bhilwara region.

Phosphorus plays an important role in root development and proliferation, thus it influences nutrient and water uptake
SKN Agriculture University, Jobner-303 328, Rajasthan, India.

Corresponding Author: Abhinav Kumar Yadav, SKN Agriculture University, Jobner-303 328, Rajasthan, India.

Email: abhinavkumaryadav1995.ay@gmail.com

How to cite this article: Yadav, A.K., Singh, S.P., Yadav, D.K., Yadav, G.K., Singh, K. and Yadav, M. (2022). Influence of Phosphorous and Foliar Nitrogen on the Growth, Quality and Yield of Kasuri Methi (Trigonella corniculata L.). Legume Research. DOI: $10.18805 / L R-4712$.

Submitted: 23-06-2021 Accepted: 10-11-2021 Online: 07-01-2022

by plant. It is also known to enhance the symbiotic nitrogen fixation by increasing nitrogenase activity of root nodules and plays an important role in energy transfer process in the plant body, which results in better uptake of nutrient and thus higher yields (Mehta et al., 2011).

Nitrogen is vital to plants because it is a major component in chlorophyll, amino acids and also required for growth of the plants. Being a leguminous crop, kasuri methi is highly responsive to foliar application of nitrogenous fertilizer especially in early stage. Nitrogen promotes the leaf, stem and other vegetative growth. It also increases the protein content (Gendy et al., 2018). The light textured soils of Rajasthan exhibited a negative balance for main nutrients due to intensive cropping and poor replenishment rate of the same (Gupta, 2001). Nitrogen application to legumes at lower doses in the initial stage is essential for vigorous start. Therefore, keeping above information in view, 
the present study was conducted to assess the suitable dose of phosphorus and nitrogen (foliar spray) to get quality produce, higher productivity and profitability of kasuri methi.

\section{MATERIALS AND METHODS}

The field experiment was conducted at Horticulture Farm, Department of Horticulture, S.K.N. college of Agriculture, Jobner (Raj.), during rabi season of 2018-19. Geographically, Jobner is situated at $26^{\circ} 5^{\prime}$ North latitude and $75^{\circ} 28^{\prime}$ East longitude at an elevation of 427 meters above mean sea level in Jaipur district of Rajasthan. In Rajasthan, this region falls under agro-climatic zone Illa (Semi-Arid Eastern Plain Zone). The soil was sandy loam in texture, alkaline in reaction $(\mathrm{pH} 8.1)$ with $0.34 \%$ organic carbon and $148,13.5$ and $176 \mathrm{~kg} / \mathrm{ha}$ of available $\mathrm{N}, \mathrm{P}$ and $\mathrm{K}$, respectively. The experiment consisted of sixteen treatment combinations including four levels of phosphorus (control, 20, 40 and 60 $\mathrm{kg} / \mathrm{ha}$ ) and four levels of foliar application of nitrogen (control, $1.0,1.5$ and $2.0 \%$ ). They were under taken in factorial randomized block design (FRBD) with three replications. Treatment was: (i) Control $0 \mathrm{~kg} / \mathrm{ha} \mathrm{P}_{2} \mathrm{O}_{5}\left(\mathrm{P}_{0}\right)$, (ii) $20 \mathrm{~kg} / \mathrm{ha}$ $\mathrm{P}_{2} \mathrm{O}_{5}\left(\mathrm{P}_{1}\right)$, (iii) $40 \mathrm{~kg} / \mathrm{ha} \mathrm{P}_{2} \mathrm{O}_{5}\left(\mathrm{P}_{2}\right)$, (iv) $60 \mathrm{~kg} / \mathrm{ha} \mathrm{P}_{2} \mathrm{O}_{5}\left(\mathrm{P}_{3}\right)$, (i) Control (water spray) $\left(\mathrm{N}_{0}\right)$, (ii) Foliar nitrogen $1.0 \%\left(\mathrm{~N}_{1}\right)$, (iii) Foliar nitrogen $1.5 \%\left(\mathrm{~N}_{2}\right)$, (iv) Foliar nitrogen $2.0 \%\left(\mathrm{~N}_{3}\right)$.

The experiment plot was ploughed thrice by tractor drawn cultivator and leveled. The clods were crushed, weeds were removed and brought to fine tilth. The land was divided into plots of required size $(2.0 \mathrm{~m} \times 1.0 \mathrm{~m})$. Provision was made for bunds and irrigation channels. The seeds of the variety pusa kasuri were used with seed rate of $8 \mathrm{~kg} / \mathrm{ha}$. It is an early bearing and high yielding variety. Seeds were sown with a spacing of $20 \times 5 \mathrm{~cm}^{2}$. Furrows were properly covered with a thin layer of soil and the plots were irrigated lightly. Excess seedlings were thinned out at 20 days after sowing, to maintain the $5 \mathrm{~cm}$ distance between the plants. The plots were kept free from weeds by hand weeding at 20 days after sowing. Irrigation was given at an interval of 10-15 days during the whole cropping period depending on the soil moisture conditions. Total of eight irrigations were given. To eliminate border effect; two rows on both sides and $0.5 \mathrm{~m}$ length at each end of the plot was not included in the experiment and net plot area was harvested separately from each plot. Data on growth and yield was recorded at harvest. Five plants for each treatment were taken for recording the various data. Leaf area per plant $\left(\mathrm{cm}^{2}\right)$ at harvest by leaf area meter (Licor-3100, Lincoln, NE, USA), chlorophyll content (mg/100 g) (Arnon, 1949), protein content in leaves (\%), nitrogen content (\%) was analyzed separately by colorimetric method (Snell and Snell, 1949) and multiplied with 6.25 factor to calculate crude protein content in leaves) and ascorbic acid in leaves (mg/100 g) (A.O.A.C., 1960), till the faint pink colour was obtained). The statistical analysis done by Panse and Sukhatme (1985).

\section{RESULTS AND DISCUSSION}

\section{Growth attributes}

\section{Plant height}

The data in Table 1 show that application of $\mathrm{P}_{2} \mathrm{O}_{5} @ 60 \mathrm{~kg} /$ ha $\left(\mathrm{P}_{3}\right)$ recorded the significantly maximum plant height at cutting-I, II, III and IV (7.64, 11.98, 11.01 and $10.74 \mathrm{~cm}$, respectively) as compared to control $P_{0}(5.82,8.06,7.21$ and $6.86 \mathrm{~cm}$, respectively) and $P_{1}(6.99,10.01,9.06$ and $9.51 \mathrm{~cm}$, respectively) but $P_{2}(7.25,11.67,10.69$ and 10.47 $\mathrm{cm}$, respectively) remains at par with $P_{3}$. Higher ratio of phosphorus application increased the plant height that may be due to favourable effect of phosphorus on nitrogen transformation leading to accumulation and metabolism of carbohydrates in plants. Similar results were reported by Kumar et al. (2016) and Datta et al. (2017). The data in Table 1 show that application of foliar nitrogen @ 2.0\% $\left(\mathrm{N}_{3}\right)$ recorded the significantly maximum plant height at cutting-

Table 1: Effect of phosphorus and foliar application of nitrogen on plant height and leaf area index at each harvest of Kasuri Methi.

\begin{tabular}{|c|c|c|c|c|c|c|c|c|}
\hline \multirow[b]{2}{*}{ Treatments } & \multicolumn{3}{|c|}{ Plant height $(\mathrm{cm})$ at each harvest } & \multicolumn{5}{|c|}{ Leaf area per plant $\left(\mathrm{cm}^{2}\right)$} \\
\hline & $\begin{array}{l}\text { I cutting } \\
40 \text { days }\end{array}$ & $\begin{array}{l}\text { Il cutting } \\
55 \text { days }\end{array}$ & $\begin{array}{l}\text { III cutting } \\
70 \text { days }\end{array}$ & $\begin{array}{l}\text { IV cutting } \\
85 \text { days }\end{array}$ & $\begin{array}{l}\text { I cutting } \\
40 \text { days }\end{array}$ & $\begin{array}{l}\text { II cutting } \\
55 \text { days }\end{array}$ & $\begin{array}{l}\text { III cutting } \\
70 \text { days }\end{array}$ & $\begin{array}{l}\text { IV cutting } \\
85 \text { days }\end{array}$ \\
\hline \multicolumn{9}{|c|}{ Phosphorus level (kg/ha) } \\
\hline $\mathrm{P}_{0}$ & 5.82 & 8.06 & 7.21 & 6.86 & 15.63 & 16.82 & 16.42 & 15.71 \\
\hline$P_{20}$ & 6.99 & 10.01 & 9.06 & 9.51 & 20.1 & 22.09 & 21.89 & 21.21 \\
\hline$P_{40}$ & 7.25 & 11.67 & 10.69 & 10.47 & 24.43 & 26.52 & 26.22 & 25.52 \\
\hline$P_{60}$ & 7.64 & 11.98 & 11.01 & 10.74 & 25.37 & 27.35 & 27.05 & 26.38 \\
\hline SEm \pm & 0.20 & 0.30 & 0.27 & 0.27 & 0.39 & 0.43 & 0.42 & 0.41 \\
\hline$C D(P=0.05)$ & 0.56 & 0.86 & 0.78 & 0.77 & 1.12 & 1.23 & 1.22 & 1.19 \\
\hline \multicolumn{9}{|c|}{ Foliar application of nitrogen through urea (\%) } \\
\hline $\mathrm{N}_{0}$ & 5.88 & 8.11 & 7.29 & 6.84 & 16.3 & 17.57 & 17.16 & 16.47 \\
\hline $\mathrm{N}_{1.0}$ & 7.05 & 10.21 & 9.29 & 8.67 & 19.49 & 22.01 & 21.84 & 21.15 \\
\hline $\mathrm{N}_{1.5}$ & 7.09 & 11.17 & 10.28 & 10.53 & 22.92 & 25.01 & 24.7 & 24.01 \\
\hline $\mathrm{N}_{2.0}$ & 7.68 & 12.23 & 11.11 & 11.54 & 26.82 & 28.18 & 27.87 & 27.18 \\
\hline SEm \pm & 0.20 & 0.30 & 0.27 & 0.27 & 0.39 & 0.43 & 0.42 & 0.41 \\
\hline$C D(P=0.05)$ & 0.56 & 0.86 & 0.78 & 0.77 & 1.12 & 1.23 & 1.22 & 1.19 \\
\hline
\end{tabular}


I, II, III and IV $(7.68,12.23,11.11$ and $11.54 \mathrm{~cm}$, respectively) as compared to control $\left(\mathrm{N}_{0}\right)(5.88,8.11,7.29$ and $6.84 \mathrm{~cm}$, respectively), foliar application of nitrogen @ 1.0\% $\left(\mathrm{N}_{1}\right)(7.05$, $10.21,9.29$ and $8.67 \mathrm{~cm}$, respectively) and $1.5 \%\left(\mathrm{~N}_{2}\right)(7.09$, $11.17,10.28$ and $10.53 \mathrm{~cm}$, respectively). The positive influence of the nitrogen on plant height might be due to the fact that nitrogen is required for cell elongation while, the plant height was least in the control. Similar findings were reported by Muniramappa et al. (1997) and Patidar et al. (2004).

\section{Leaf area per plant $\left(\mathrm{cm}^{2}\right)$}

The data in Table 1 show that application of $\mathrm{P}_{2} \mathrm{O}_{5} @ 60 \mathrm{~kg} /$ ha $\left(\mathrm{P}_{3}\right)$ recorded the significantly maximum leaf area at cutting-I, II, III and IV (25.37, 27.35, 27.05 and $26.38 \mathrm{~cm}^{2}$ I plant, respectively) as compared to control $\mathrm{P}_{0}(15.63,16.82$, 16.42 and $15.71 \mathrm{~cm}^{2} /$ plant, respectively) and $P_{1}(20.10$, $22.09,21.89$ and $21.21 \mathrm{~cm}^{2} /$ plant, respectively) but $P_{2}$ (24.43, 26.52, 26.22 and $25.52 \mathrm{~cm}^{2} /$ plant, respectively) remains at par with $\mathrm{P}_{3}$. Increased leaf area per plant during periodic stages probably resulted in more interception of solar radiation and also phosphorus is noted especially for its role in capturing and converting the sun's energy into useful plant compounds leading to formation of greater amount of photosynthates. Similar findings were reported by Jat et al. (2013) and Dar et al. (2016). The data in Table 1 show that application of foliar nitrogen @ 2.0\% $\left(\mathrm{N}_{3}\right)$ recorded the significantly maximum leaf area per plant at cutting-I, II, III and IV (26.82, 28.18, 27.87 and $27.18 \mathrm{~cm}^{2} /$ plant, respectively) as compared to control $\left(\mathrm{N}_{0}\right)(16.30,17.57$, 17.16 and $16.47 \mathrm{~cm}^{2} /$ plant, respectively), foliar application of nitrogen @ $1.0 \%\left(\mathrm{~N}_{1}\right)(19.49,22.01,21.84$ and 21.15 $\mathrm{cm}^{2} /$ plant, respectively) and $1.5 \%\left(\mathrm{~N}_{2}\right)(22.92,25.01,24.70$ and $24.01 \mathrm{~cm}^{2} /$ plant, respectively). Linear increases in leaf area per plant were observed with increase in the foliar application of nitrogen levels. This could be due to production of more number of leaves, branches and enhanced availability of nitrogen at the appropriate time, which has increased the leaf area per plant. Similar results were noticed by Mehta et al. (2010) and Anupama et al. (2017).

\section{Number of nodules per plant}

The data in Fig 1 indicated that application of $60 \mathrm{~kg} / \mathrm{ha}$ dose of $\left(\mathrm{P}_{3}\right)$ fertilizer recorded the significantly maximum number of nodules per plant (58.17) as compared to $\mathrm{P}_{0}$ (control) (46.87) and $P_{1}$ (48.13) but $P_{2}(56.20)$ remains at par with $P_{3}$. The adequate supply of phosphorus improved survival and growth of rhizobia, rate of symbiotic infection and microbial activity in plant root nodules. Valverde et al. (2002) and Singh et al. (2012) observed in their study on Discaria trinervis that the size of nodules and the proportion of nodule tissue were stimulated by phosphorus application. The data in Fig 1 show that foliar nitrogen @ 2\% $\left(\mathrm{N}_{3}\right)$ recorded highest number of nodules/plant (53.33), which found non-significant among each other. These results were similar with the findings of Roy et al. (2016) and Shete et al. (2018).

\section{Chlorophyll content (mg/100 g)}

The data in Table 2 show that application of $60 \mathrm{~kg} / \mathrm{ha}$ dose of $\mathrm{P}_{2} \mathrm{O}_{5}\left(\mathrm{P}_{3}\right)$ fertilizer recorded the significantly maximum total chlorophyll content $(2.32 \mathrm{mg} / 100 \mathrm{~g})$ in plant leaves as compared to $P_{0}$ (control) $(1.79 \mathrm{mg} / 100 \mathrm{~g})$ and $P_{1}(2.06 \mathrm{mg} /$ $100 \mathrm{~g})$ but remains at par with $P_{2}(2.25 \mathrm{mg} / 100 \mathrm{~g})$. Phosphorus is a necessary nutrient for the biosynthesis of chlorophyll, so higher amount of phosphorus leads to higher chlorophyll content of leaves (Ambrose and Easty, 1977). Similar results were recorded by Dar et al. (2015) and Gendy et al. (2018). Application of foliar nitrogen @ 2.0\% $\left(\mathrm{N}_{3}\right)$ recorded the significantly maximum total chlorophyll content $(2.39 \mathrm{mg} / 100 \mathrm{~g})$ as compared to control $\left(\mathrm{N}_{0}\right)(1.87 \mathrm{mg} / 100 \mathrm{~g})$, foliar application of nitrogen @ 1.0\% $\left(\mathrm{N}_{1}\right)(2.02 \mathrm{mg} / 100 \mathrm{~g})$ and $1.5 \%\left(\mathrm{~N}_{2}\right)(2.14 \mathrm{mg} / 100 \mathrm{~g})$. This might be due to increased nitrogen supply which would retard leaf

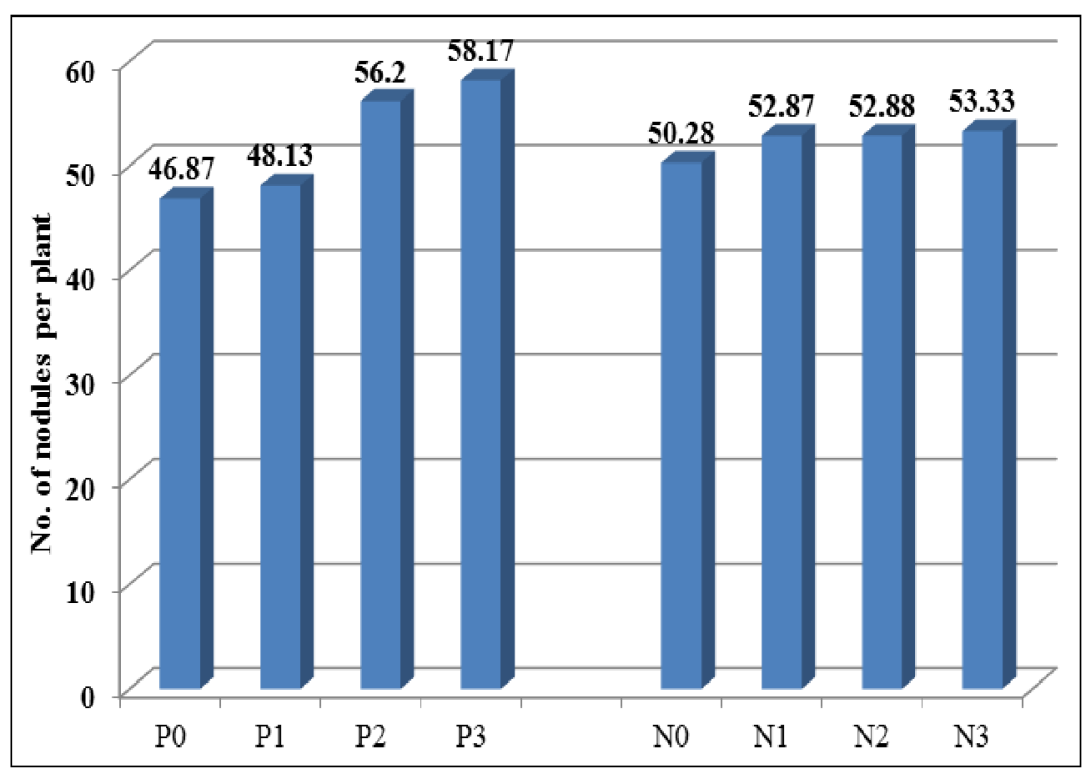

Fig 1: Effect of phosphorus and foliar application of nitrogen on no. of nodules/plant. 
Influence of Phosphorous and Foliar Nitrogen on the Growth, Quality and Yield of Kasuri Methi (Trigonella corniculata L.)

Table 2: Effect of phosphorus and foliar application of nitrogen on number of chlorophyll, crude protein and ascorbic acid content in leaves of kasuri Methi.

\begin{tabular}{lccc}
\hline Treatments & Chlorophyll content $(\mathrm{mg} / 100 \mathrm{~g})$ & Crude protein content in leaves $(\%)$ & Ascorbic acidcontent $(\mathrm{mg} / 100 \mathrm{~g})$ \\
\hline & & Phosphorus level $(\mathbf{k g} / \mathbf{h a})$ & 182.42 \\
$\mathrm{P}_{0}$ & 1.79 & 3.72 & 205.15 \\
$\mathrm{P}_{20}$ & 2.06 & 4.34 & 215.34 \\
$\mathrm{P}_{40}$ & 2.25 & 5.13 & 218.15 \\
$\mathrm{P}_{60}$ & 2.32 & 5.28 & 3.68 \\
$\mathrm{SEm} \pm$ & 0.02 & 0.06 & 10.62 \\
$\mathrm{CD}(\mathrm{P}=0.05)$ & 0.07 & 0.17 & 188.86 \\
& & Foliar application of nitrogen through urea (\%) \\
$\mathrm{N}_{0}$ & 1.87 & 3.6 & 199.74 \\
$\mathrm{~N}_{1.0}$ & 2.02 & 3.98 & 210.04 \\
$\mathrm{~N}_{1.5}$ & 2.14 & 5.14 & 222.42 \\
$\mathrm{~N}_{2.0}$ & 2.39 & 5.75 & 3.68 \\
$\mathrm{SEm} \pm$ & 0.02 & 0.06 & 10.62 \\
$\mathrm{CD}(\mathrm{P}=0.05)$ & 0.07 & 0.17 & \\
\hline
\end{tabular}

Table 3: Effect of phosphorus and foliar application of nitrogen on fresh and dry yield of Kasuri Methi.

\begin{tabular}{|c|c|c|c|c|}
\hline \multirow{2}{*}{ Treatments } & \multicolumn{2}{|c|}{ Fresh leaves yield } & \multicolumn{2}{|c|}{ Dry leaves yield } \\
\hline & (kg/plot) & (q/ha) & (kg/plot) & (q/ha) \\
\hline \multicolumn{5}{|c|}{ Phosphorus level (kg/ha) } \\
\hline $\mathbf{P}_{0}$ & 2.29 & 114.50 & 0.26 & 12.90 \\
\hline $\mathbf{P}_{20}$ & 2.46 & 123.10 & 0.31 & 15.29 \\
\hline $\mathbf{P}_{40}$ & 2.63 & 131.50 & 0.38 & 19.07 \\
\hline $\mathbf{P}_{60}$ & 2.78 & 139.10 & 0.40 & 20.01 \\
\hline SEm \pm & 0.07 & 3.61 & 0.01 & 0.33 \\
\hline$C D(P=0.05)$ & 0.21 & 10.42 & 0.02 & 0.95 \\
\hline \multicolumn{5}{|c|}{ Foliar application of nitrogen through urea (\%) } \\
\hline $\mathbf{N}_{0}$ & 2.22 & 111.19 & 0.24 & 11.73 \\
\hline $\mathbf{N}_{1.0}$ & 2.49 & 124.48 & 0.29 & 14.87 \\
\hline $\mathbf{N}_{1.5}$ & 2.62 & 130.87 & 0.36 & 18.30 \\
\hline $\mathbf{N}_{2.0}$ & 2.83 & 141.66 & 0.44 & 22.38 \\
\hline SEm \pm & 0.07 & 3.61 & 0.01 & 0.33 \\
\hline$C D(P=0.05)$ & 0.21 & 10.42 & 0.019 & 0.95 \\
\hline
\end{tabular}

senescence and improve photosynthate and nitrogen availability for seed biomass. These results obtained are closely similar with earlier findings recorded by Mitra and Ghildiyal (1988) and Kulsum et al. (2007).

\section{Fresh leaves yield}

The data in Table 3 show that application of $\mathrm{P}_{2} \mathrm{O}_{5} @ 60 \mathrm{~kg} /$ ha $\left(\mathrm{P}_{3}\right)$ recorded significantly maximum total fresh leaves yield per plot $(\mathrm{kg})$ and per hectare $(\mathrm{q})(0.567$ and 139.10) as compared to control $\left(P_{0}\right)(0.447$ and 114.50$)$ and $P_{1}(0.499$ and 123.10) but remains at par with $P_{2}(0.551$ and 131.5). Application of phosphorus increased nutrients availability to the crop during the growing season which led to greater synthesis and utilization of assimilates into the leaves and ultimately improved the performance of various yield attributes viz. fresh leaves yield per plot $(\mathrm{kg})$ and per hectare (q). Similar results were noticed by Sharma et al. (2014) and Nikfarjam and Aminpanah (2015). Application of foliar nitrogen @ 2.0\% $\left(\mathrm{N}_{3}\right)$ enhanced the total fresh leaves yield per plot $(\mathrm{kg})$ and per hectare $(\mathrm{q})$ (0.580 and 141.66) significantly over control $\left(\mathrm{N}_{0}\right)(0.458$ and 111.19$), \mathrm{N}_{1}(0.498$ and 124.48) and $N_{2}(0.528$ and 130.87). The increased levels of foliar nitrogen enhanced the metabolic process like photosynthesis, levels of nucleic acids, soluble proteins, carbohydrates, which results in luxuriant growth of the plant and production of more fresh yield. These results similar with the findings of Meena et al. (2006) and Khan et al. (2018).

\section{Dry leaves yield}

The data in Table 3 show that application of $\mathrm{P}_{2} \mathrm{O}_{5} @ 60 \mathrm{~kg} /$ ha $\left(P_{3}\right)$ recorded significantly maximum total dry leaves yield per plot $(\mathrm{kg})$ and per hectare $(q)$ (0.027 and 20.01) as compared to $P_{0}$ (control) $\left(0.022\right.$ and 12.90) and $P_{1}(0.024$ 
Table 4: Effect of phosphorus and foliar application of nitrogen on net return and $B: C$ ratio of kasuri methi.

\begin{tabular}{lcc}
\hline Treatments & Net return (Rs/ha) & B:C ratio \\
\hline & \multicolumn{1}{c}{ Phosphorus level (kg/ha) } \\
$\mathrm{P}_{0}$ & 70161 & 0.93 \\
$\mathrm{P}_{20}$ & 95849 & 1.26 \\
$\mathrm{P}_{40}$ & 137174 & 1.77 \\
$\mathrm{P}_{60}$ & 146549 & 1.86 \\
$\mathrm{SEm} \pm$ & 3353 & 0.03 \\
$\mathrm{CD}(\mathrm{P}=0.05)$ & 9685 & 0.09 \\
& Foliar application of nitrogen through urea (\%) \\
$\mathrm{N}_{0}$ & 55477 & 0.72 \\
$\mathrm{~N}_{1.0}$ & 90532 & 1.17 \\
$\mathrm{~N}_{1.5}$ & 128982 & 1.67 \\
$\mathrm{~N}_{2.0}$ & 174742 & 2.26 \\
$\mathrm{SEm} \pm$ & 3353 & 0.03 \\
$\mathrm{CD}(\mathrm{P}=0.05)$ & 9685 & 0.09 \\
\hline
\end{tabular}

and 15.29) but remains at par with $P_{2}(0.026$ and 19.07 , respectively). Adequate level of phosphorus along with increased mobility of other nutrients had a strong positive effect on photosynthesis that could enhance the plant's ability to produce more assimilates which were reflected in the higher amount of dry matter accumulation at an accelerated pace as evidenced from high leaf area per plant values resulting in higher amount of biomass. Similar results were noticed by Godara et al. (2013) and Singh et al. (2014). Application of foliar nitrogen @ 2.0\% $\left(\mathrm{N}_{3}\right)$ enhanced the total dry leaves yield per plot $(\mathrm{kg})$ and per hectare $(\mathrm{q})$ (0.028 and $22.38)$ significantly over control $\left(\mathrm{N}_{0}\right)(0.22$ and 11.73$), \mathrm{N}_{1}$ (0.024 and 14.87) and $N_{2}(0.026$ and 18.30). Foliar nitrogen preferentially increased the metabolic processes like photosynthesis, enhanced levels of nucleic acids, soluble proteins and carbohydrates which resulted in higher dry matter production and sink size. Similar results were observed by Godara et al. (2018) and Bhadru et al. (2019).

\section{Quality attributes}

\section{Crude protein content in leaves (\%)}

The data in Table 2 show that application of $\mathrm{P}_{2} \mathrm{O}_{5} @ 60 \mathrm{~kg} /$ ha $\left(\mathrm{P}_{3}\right)$ recorded significantly maximum crude protein content (5.28\%) over $\mathrm{P}_{0}$ (control) $(3.72 \%)$ and $\mathrm{P}_{1}(4.34 \%)$ but remains at par with $P_{2}(5.13 \%)$. The increase in these parameters due to $P$ fertilization led to an increased uptake of nutrient in the present study. Higher nitrogen in plant parts is directly responsible for higher protein because it is a primary component of amino acids which constitute the basis of protein. These results are in close conformity with the findings of Gupta et al. (2009) and Dubey et al. (2012). Data in Table 2 show that significantly maximum crude protein content was recorded under foliar nitrogen @ 2.0\% $\left(\mathrm{N}_{3}\right)$ $(5.75 \%)$ over control $\left(\mathrm{N}_{0}\right)(3.60 \%), \mathrm{N}_{1}(3.98 \%)$ and $\mathrm{N}_{2}(5.14)$. Higher nitrogen in plant parts is directly responsible for higher protein because it is a primary component of amino acids which constitute the basis of protein. Similar results were observed by Pandya and Bhatt (2007) and Naveen (2010).

\section{Ascorbic acid content in leaves ( $\mathrm{mg} / 100 \mathrm{~g}$ )}

Table 2 shows that ascorbic acid content in leaves was recorded significantly maximum with application of $\mathrm{P}_{2} \mathrm{O}_{5} @$ $60 \mathrm{~kg} / \mathrm{ha}\left(\mathrm{P}_{3}\right)(218.15 \mathrm{mg} / 100 \mathrm{~g})$ over $\mathrm{P}_{0}$ (control) (182.42 $\mathrm{mg} / 100 \mathrm{~g})$ and $P_{1}(205.15 \mathrm{mg} / 100 \mathrm{~g})$ but remains at par with $\mathrm{P}_{2}(215.34 \mathrm{mg} / 100 \mathrm{~g})$. Similar findings were reported by Singh et al. (2012) and Zikalala et al. (2016). Table 2 further shows that significantly maximum ascorbic acid content in leaves was recorded under foliar application of nitrogen @ $2.0 \%\left(\mathrm{~N}_{3}\right)(222.42 \mathrm{mg} / 100 \mathrm{~g})$ over control $\left(\mathrm{N}_{0}\right)(188.86 \mathrm{mg} /$ $100 \mathrm{~g}), \mathrm{N}_{1}(199.74 \mathrm{mg} / 100 \mathrm{~g})$ and $\mathrm{N}_{2}(210.04 \mathrm{mg} / 100 \mathrm{~g})$. Similar results were noticed by Moreira et al. (2003) and Gupta et al. (2009).

\section{Economics}

Table 4 shows that application of $\mathrm{P}_{2} \mathrm{O}_{5} @ 60 \mathrm{~kg} / \mathrm{ha}\left(\mathrm{P}_{3}\right)$ recorded significantly higher net return and $\mathrm{B}: \mathrm{C}$ ratio (Rs. 162430 and 2.57) over control $P_{0}$ and $P_{1}$ but remains at par with $\mathrm{P}_{2}$. Similar findings were reported by Bhunia et al. (2006) and Godara et al. (2017). Table 4 shows that application of foliar application of nitrogen @ 2.0\% $\left(\mathrm{N}_{3}\right)$ recorded significantly higher net return and $\mathrm{B}: \mathrm{C}$ ratio (Rs. 188536 and 2.97) over $\mathrm{N}_{0}$ (control), $\mathrm{N}_{1}$ and $\mathrm{N}_{2}$. Similar results were reported by Godara et al. (2018) and Dhaka et al. (2020).

\section{CONCLUSION}

On the basis of one year experimental results, it may be concluded that application of $60 \mathrm{~kg} / \mathrm{ha} \mathrm{P}_{2} \mathrm{O}_{5}\left(\mathrm{P}_{3}\right)$ was found significantly better in terms of growth, quality, yield and monetary value. However application of $40 \mathrm{~kg} / \mathrm{ha} \mathrm{P}_{2} \mathrm{O}_{5}\left(\mathrm{P}_{2}\right)$ was found at par with $60 \mathrm{~kg} / \mathrm{ha} \mathrm{P}_{2} \mathrm{O}_{5}\left(\mathrm{P}_{3}\right)$, while, Foliar application of nitrogen @ 2.0\% $\left(\mathrm{N}_{3}\right)$ was found significantly better in terms of growth, quality, yield and monetary value. Thus, application of $40 \mathrm{~kg} / \mathrm{ha} \mathrm{P}_{2} \mathrm{O}_{5}\left(\mathrm{P}_{2}\right)$ and foliar application of nitrogen @ 2.0\% $\left(\mathrm{N}_{3}\right)$ may be recommended for kasuri methi crop.

\section{REFERENCES}

A.O.A.C. (1960). Official Methods of Analysis, 18 Edn. Association of Official Agricultural Chemists. Washington.

Ambrose, E.J. and Easty, D.M. (1977). Cell Biology. The English Language Book Society and Longman. London.

Anonymous (2017). Indian Horticulture Database, Ministry of Agriculture, Government of India.

Anupama, G., Hegde, L.N., Hegde, N.K., Devappa, V., Mastiholi, A.B. and Nishani, S. (2017). Effect of nitrogen and spacing levels on physiological and yield parameters of Kasuri Methi (Trigonella corniculata L.) var. Pusa Kasuri. International Journal of Current Microbiology and Applied Sciences. 6(9): 723-733.

Anwer, M.M., Kakani, R.K. and Khan, M.A. (2011). India's response to World demand of seed spices. International Journal of Seed Spices. 1(1): 1-7. 
Arnon, D.I. (1949). Copper enzymes in isolated chloroplast polyphenol oxidase in Beta vulgaris. Plant Physiology. 24: 1-5.

Bhadru, P., Yadav, S.S., Bijarnia, A., Kumawat, R. and Choudhary, R. (2019). Effect of zinc and thiourea application on growth, yield and nutrient uptake of greengram [Vigna radiata (L.) Wilczek]. Journal of Pharmacognosy and Phytochemistry. 8(5): 2404-2408.

Bhunia, S.R., Chauhan, R.P.S., Yadav, B.S. and Bhati, A.S. (2006). Effect of phosphorus, irrigation and Rhizobium on productivity, water use and nutrient uptake in fenugreek (Trigonella foenum-graecum L.). Indian Journal of Agronomy. 51(3): 239-241.

Dar, T.A., Uddin, M., Khan, M.M.A., Ali, A. and Varshney, L. (2016). Modulation of alkaloid content, growth and productivity of Trigonella foenum-graecum L. using irradiated sodium alginate in combination with soil applied phosphorus. Journal of Applied Research on Medicinal and Aromatic Plants. 3(4): 200-210.

Dar, T.A., Uddin, M., Khan, M.M.A., Ali, A., Hashmi, N. and Idrees, M. (2015). Cumulative effect of gibberellic acid and phosphorus on crop productivity, biochemical activities and trigonelline production in Trigonella foenum-graecum L. Cogent Food and Agriculture. 1: 995950.

Datta, N., Hore, J.K. and Sarkar, T. (2017). Growth and yield of fenugreek (Trigonella foenum-graecum L.) as influenced by different levels of NPK under new alluvial plains of West Bengal, India. International Journal of Current Microbiology and Applied Sciences. 6(9): 2304-2312.

Dhaka, A.K., Kumar, S., Singh, B., Singh, K., Kumar, A. and Kumar, N. (2020). Nitrogen use efficiency, economic return and yield performance of Pigeonpea [Cajanus cajan (L.) Millsp.] as influenced by nipping and fertility levels. Legume Research. 43(1): 105-110.

Dubey, P.K., Pandey, C.S., Khanday, S. and Mishra, G. (2012). Effect of integrated nutrient management on nutrient uptake, protein content and yield of fenugreek. International Journal of Food, Agriculture and Veterinary Sciences. 2(1): 12 .

Gendy, A.S., Abdelkader, M.A., Naggar, N.Z. and Elakkad, H.A. (2018). Effect of intercropping systems and NPK foliar application on productivity and competition indices of black cumin and fenugreek. Current Science International. 7(3): 387-401.

Godara, A.S., Kapade, S., Lal, G. and Singh, R. (2013). Effect of phosphorus and sulphur levels on the performance of Nagauri Methi (Trigonella corniculata L.) under semi arid areas of Rajasthan. International Journal of Seed Spices. 3(2): 70-73.

Godara, A.S., Singh, R. and Chouhan, G.S. (2018). Fenugreek productivity and $\mathrm{N}$ and $\mathrm{P}$ balance sheet with varying fertilizer levels, biofertilizers and brassinosteroid in Typic Haplustepts. Legume Research. 41(4): 598-601.

Godara, A.S., Singh, R., Chouhan, G.S. and Nepalia, V. (2017). Yield and economics of fenugreek (Trigonella foenumgraecum L.) as influenced by fertility levels, biofertilizers and brassinosteroid. Legume Research. 40(1): 165-169.

Gupta, A.K. (2001). Nutrient minising in agro climatic zones of Rajasthan. Fertilizer News (Now Indian Journal of Fertilisers). 46(9): 39-46.
Gupta, S.C., Singh, R.P. and Verma, R. (2009). Response of chickpea to $P$ levels from different sources with various PSB species. Legume Research. 32(3): 212-214.

Jat, S.R., Patel, B.J., Shivran, A.C., Kuri, B.R. and Jat, G. (2013). Effect of $P$ and $S$ levels on growth and yield of cowpea under rainfed conditions. Annals of Plant and Soil Research, 15: $114-117$.

Khan, E.A., Hussain, I., Ahmad, H.B. and Hussain, I. (2018). Influence of nipping and foliar application of nutrients on growth and yield of chickpea in rain-fed condition. Legume Research. 41(5): 740-744.

Kulsum, M.U., Baque, M.A. and Karim, M.A. (2007). Effect of Different Nitrogen levels on the leaf chlorophyll content nutrient concentration and nutrient uptake pattern of black gram. Pakistan Journal of Biological Science. 10: 250-254.

Kumar, M. and Kumar, V. (2016). Effect of nitrogen, phosphorus and cutting management on flowering and yield of green leaves of fenugreek (Trigonella foenum graecum L.). Annals of Horticulture. 2: 220-224.

Meena, S.S., Sen, N.L. and Malhotra, S.K. (2006). Influence of nitrogen on growth and yield of Coriander (Coriandrum sativum L.). Journal of Spices and Aromatics Crops. 15(2): 88-92.

Mehta, R.S., Patel, B.S. and Jat, R.A. (2011). Effect of nitrogen, phosphorus and biofertilizer inoculation on growth, productivity, nutrient uptake and economic return in fenugreek (Trigonella foenum graecum L.). Indian Journal of Dryland Agriculture Research and Development. 26(1): 102-108.

Mehta, R.S., Patel, B.S., Meena, S.S. and Meena, R.S. (2010). Influence of growth characters and yield of fenugreek (Trigonella foenum-graecum). Journal of Medicinal and Aromatic Plant Science. 19(2): 23-28.

Mitra, S. and Ghildiyal, M.C. (1988). Photosynthesis and assimilate partitioning in mungbean in response to source sink alteration. Journal of Agronomy and Crop Science. 16: 303-308.

Moreira, M.D.R., Roura, S.I. and del Valle, C.E. (2003). Quality of Swiss chard produced by conventional and organic methods. LWT-Food Science and Technology. 36(1): 135141.

Muniramappa, R.P., Farooqi, A.A., Rudregowda, H.G. and Maricapu, S. (1997). Influence of macro nutrients on yield and active principle content in kalmegh (Andrographis paniculata). Journal of Medicinal and Aromatic Plant Sciences. 19: 1039-1042.

Naveen, M.N. (2010). Standardization of nutrient requirement of kasuri methi (Trigonella corniculata L.). M. Sc. (Hort.) Thesis, University of Agricultural Sciences. Bangalore.

Nikfarjam, S.G. and Aminpanah, H. (2015). Effects of phosphorus fertilization and Pseudomonas fluorescens strain on the growth and yield of faba bean (Vicia faba L.). IDESIA (Chile). 33(4): 15-21.

Pandya, C.B. and Bhatt, V.R. (2007). Effect of different nutrient levels on yield and nutrient content of fodder cowpea. Legume Research. 30(3): 218-220.

Panse, V.G. and Sukhatme, P.U. (1985). Statistical Methods for Agricultural Workers, fourth England Edition, ICAR, New Delhi. 
Patidar, M., Balaram, B., Singh, M.P. and Singh, G. (2004). Influence of nitrogen on growth and yield of Cumin (Cuminum cyminum L.). Journal for Spices and Aromatics Crops. 13(2): 126-128.

Roy, S., Gunri, S.K., Puste, A.M., Sengupta, A. and Saha, D. (2016). Growth and yield of summer groundnut (Arachis hypogaea L.) as influenced by foliar application of water soluble fertilizer. Journal of Applied and Natural Science. 8(1): 245-250.

Sharma, S., Sharma, Y. and Balai, C.M. (2014). Yield attributes and yield of fenugreek (Trigonella foenum-graecum) under different levels phosphorous, molybdenum and inoculation of PSB. Agriculture Update. 9(3): 301-305.

Shete, S.A., Bulbule, A.V., Patil, D.S. and Pawar, R.B. (2018). Effect of foliar nutrition on growth and uptake of macro and micronutrients of kharif groundnut (Arachis hypogaea L.). International Journal of Current Microbiology and Applied Sciences. 7(10): 1193-1200.
Singh, S., Choudhary, M.R., Garhwal, O.P., Jakhar, M.L. and Yadav, B.L. (2012). Effect of biofertilizers and inorganic sources of Nitrogen and Phosphorus on quality production of kasuri methi (Trigonella corniculata). International Journal of Seed Spices. 2(2): 38-40.

Singh, S.K., Singh, S.P. and Chand, G. (2014). Effect of phosphorus, sulphur and zinc on plant height, green leaves, pod per plant, grain yield per plant and straw yield per plant of black gram. The Journal of Rural and Agricultural Research. 14(1): 49-51.

Snell, F.D. and Snell, C.T. (1949). Colorimetric methods and analysis. $3^{\text {rd }}$ edition. Vol. 116. Van North and co. inc. New Delhi.

Valverde, C., Ferrari, A. and Wall, L. (2002). Phosphorus and the regulation of nodulation in the actinorhizal symbiosis between Discaria trinervis (Rhamnaceae) and Frankia. New Phytologist. 153: 43-51.

Zikalala, B.O., Nkomo, M., Araya, H.T., Ngezimana, W. and Mudau, F.N. (2016). Nutritional quality of baby spinach (Spinacia oleracea L.) as affected by nitrogen, phosphorus and potassium fertilization. South African Journal of Plant and Soil. 4(1): 8 . 